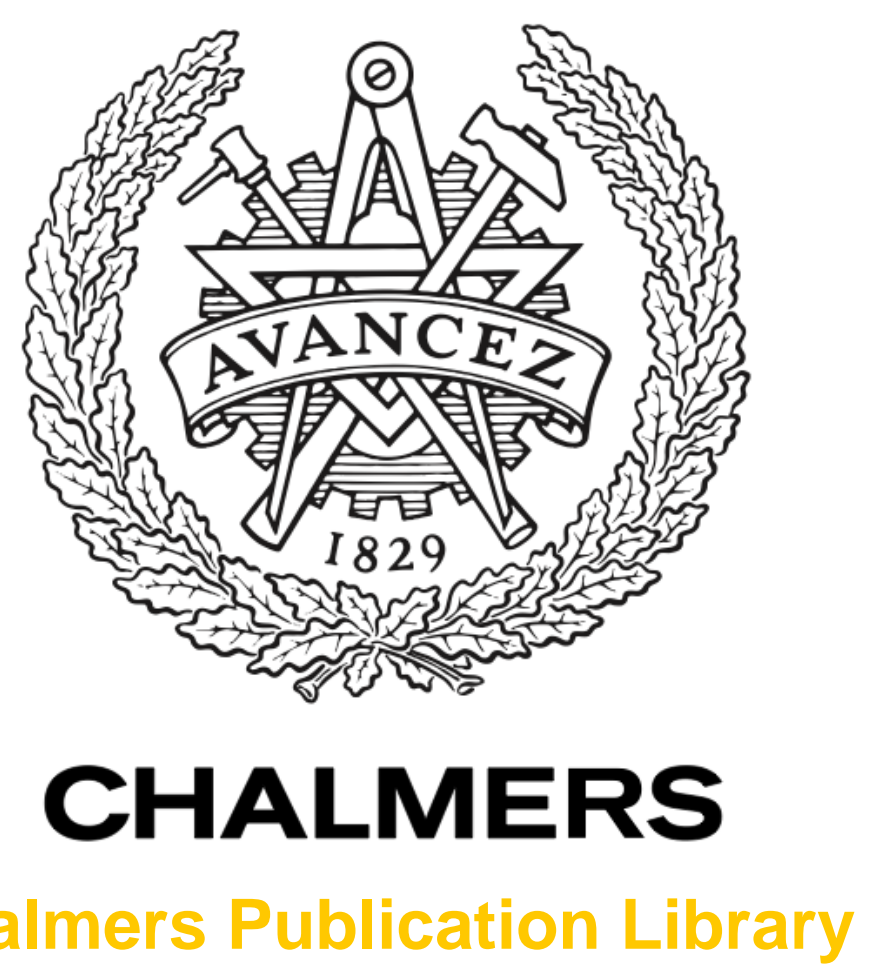

\title{
Speciation of Copper in Ash from a Fluidized-Bed Boiler Fired with Municipal Solid Waste
}

This document has been downloaded from Chalmers Publication Library (CPL). It is the author's version of a work that was accepted for publication in:

Energy \& Fuels (ISSN: 0887-0624)

Citation for the published paper:

Lassesson, H. ; Steenari, B. (2013) "Speciation of Copper in Ash from a Fluidized-Bed Boiler Fired with Municipal Solid Waste". Energy \& Fuels, vol. 27(7), pp. 3891-3897.

http://dx.doi.org/10.1021/ef400386j

Downloaded from: http://publications.lib.chalmers.se/publication/182060

Notice: Changes introduced as a result of publishing processes such as copy-editing and formatting may not be reflected in this document. For a definitive version of this work, please refer to the published source. Please note that access to the published version might require a subscription.

Chalmers Publication Library (CPL) offers the possibility of retrieving research publications produced at Chalmers University of Technology. It covers all types of publications: articles, dissertations, licentiate theses, masters theses, conference papers, reports etc. Since 2006 it is the official tool for Chalmers official publication statistics. To ensure that Chalmers research results are disseminated as widely as possible, an Open Access Policy has been adopted.

The CPL service is administrated and maintained by Chalmers Library. 


\title{
Speciation of $\mathrm{Cu}$ in ash from a fluidized bed boiler fired with municipal solid waste
}

\author{
Henric Lassesson $^{* 1}$, Britt-Marie Steenari ${ }^{1}$ \\ ${ }^{1}$ Department of Chemical and Biological Engineering, Industrial Materials Recycling, Chalmers \\ University of Technology, SE-412 96 Göteborg, Sweden
}

Keywords: MSWI fly ash, copper compounds, metal speciation, XANES, EXAFS, X-Ray absorption spectroscopy

ABSTRACT: Copper is one of the most important trace elements in municipal solid waste (MSW) combustion. Knowledge of the speciation of copper is fundamental for the understanding of the effects of copper compounds on the combustion chemistry, for the evaluation of the environmental effects of copper in ash leachates and for the development of methods to recover copper from the MSW combustion ash. In this work an investigation of the speciation of copper in four ash flows from a bubbling fluidized bed boiler using synchrotron based X-ray absorption spectrometry is reported. The results showed that copper occurs in oxidation states zero, $+\mathrm{I}$ and + II in the bed ash and the cyclone ash, i.e. 10-20\% Cu(0), 25-35\% Cu(I), 50-60\% $\mathrm{Cu}(\mathrm{II})$, whereas the filter ash contained copper only in oxidation state + II. The most common copper compounds in the bed ash are copper metal, $\mathrm{Cu}_{2} \mathrm{O}, \mathrm{CuO}$ and mixed oxides, such as $\mathrm{CuCr}_{2} \mathrm{O}_{4}$. The cyclone ash probably contained a mix of copper metal, $\mathrm{Cu}_{2} \mathrm{O}, \mathrm{CuCl}, \mathrm{Cu}(\mathrm{OH})_{2}$ and $\mathrm{CuSO}_{4} \cdot 5 \mathrm{H}_{2} \mathrm{O}$, 
possibly also CuO. Copper sulfate was found as one of the major species in the filter ash together with a mix of hydroxides and chlorides.

\section{INTRODUCTION}

Copper is one of the more abundant trace metals in municipal solid waste (MSW). It is a micronutrient and will therefore occur in small amounts in biomaterials going to combustion. The reason why it occurs in relatively high concentrations in MSW is that it is used in many appliances in society. It can be seen from studies of Swedish and Danish household waste that copper is present in high concentrations in several waste material fractions, which makes it difficult to determine its main source. Small but highly contaminated fractions, e.g. misplaced batteries and electronic waste (WEEE), can however be responsible for a large part of the total amount of copper, as well as for fluctuations seen in copper concentrations, in MSW going to incineration ${ }^{1-5}$.

Copper is an important micronutrient, but it is also toxic in too high amounts. Therefore, there is a risk that ashes from municipal solid waste incineration (MSWI) can increase the copper levels in soil and water to a toxic level if the ashes are exposed to leaching by rain. Hence it is beneficial if the copper is non-soluble if the ash is to be landfilled, recycled as construction material or in any other way left open to rain leaching. Copper has also been identified as one of the most important elements contributing to dioxin formation within the boiler. The effect does however depend on the chemical form of copper, e.g. $\mathrm{CuCl}_{2}$ is an active catalyst while $\mathrm{CuSO}_{4}$ is less active ${ }^{6}$. Copper is also a metal with high value, which makes it interesting for recycling. An efficient recycling process for copper from MSWI ash could be beneficial both economically as well as ecologically ${ }^{7-8}$. 
A better understanding of the chemical composition of copper in the different ash flows and within the boiler, with MSW as fuel, could be beneficial to all these areas of research.

Unfortunately, due to the detection limits of commonly available analytical methods (e.g. XRD) combined with low concentrations of copper, the identification of copper compounds in ashes is difficult to achieve. Selective sequential extraction protocols ${ }^{9-10}$ has been heavily relied on so far for speciation of metals in solid samples, such as soil and ash. The sequential extraction will, however, lead to chemical and physical alterations in the major matrix compounds and thereby also chemical transformation of the trace metal compounds. The experimental results will be significantly influenced by such processes ${ }^{11-12}$.

Synchrotron based X-ray absorption spectroscopy (XAS), on the other hand, is an alternative method that can be applied to the solid material without the need for dissolution or heating of the sample. XAS is element specific and gives low detection limits as well as an insignificant influence from the bulk matrix.

Some results from speciation of copper in ashes by XAS can be found in literature ${ }^{13-23}$. In most of these investigations only the fly ashes were studied. The results indicate that $\mathrm{Cu}(\mathrm{II})$ is the most common oxidation state in fly ashes and that oxides, hydroxides, chlorides and sulfates are the most common compounds, in varying concentrations.

The aim of this work was to clarify the chemical speciation of copper in the different ash flows from a bubbling fluidized bed boiler fired with municipal solid waste.

\section{MATERIALS AND METHODS}

The ash samples included in this investigation originate from combustion of MSW in a bubbling fluidized bed boiler (BFB) with a combustion temperature between 780 and $850^{\circ} \mathrm{C}$. The bottom ash was collected from a tank beneath the furnace. The hopper ash was collected in a 
chamber beside the furnace, after an empty cooling pass, before the super heater. Both these flows are usually combined as one single "bed ash" flow. Particles in the flue gases are collected in a cyclone (cyclone ash) and a bag house filter (filter ash). The boiler has a lime $\left(\mathrm{Ca}(\mathrm{OH})_{2}\right)$ injection system placed before the textile filter. Household waste was the main fuel with minor additions of waste, e.g. plastics, wood and paper, from local enterprises. Approximately $85 \%$ of the ferrous metal was removed from the fuel before combustion. The boiler has been described further by Abbas and coworkers ${ }^{24-25}$.

The element concentrations in the ash samples were determined using ICP-AES for main elements and ICP-MS for minor and trace elements after total dissolution of the ash. The main crystalline compounds in the ashes were identified by qualitative X-ray powder diffractometry (XRD) using a Siemens D5000 X-ray powder diffractometer with the characteristic Cu radiation and a scintillation detector. The identification of compounds was performed through comparison with standards in the Joint Committee of Powder Diffraction Standards.

Speciation of $\mathrm{Cu}$ in ash samples was investigated using X-ray absorption spectroscopy (XAS) measurements at the MAX-lab synchrotron, managed by Lund University, Sweden. In addition to data for the ash samples, XAS data were also collected for a number of model compounds that were considered possible to find in ashes. The following 18 standard compounds were used: $\mathrm{Cu}$, brass, $\mathrm{Cu}_{2} \mathrm{O}, \mathrm{CuO}, \mathrm{CuCrO}_{2}, \mathrm{CuCr}_{2} \mathrm{O}_{4}, \mathrm{CuFe}_{2} \mathrm{O}_{4}, \mathrm{Cu}_{3}\left(\mathrm{PO}_{4}\right)_{2}, \mathrm{CuCl}, \mathrm{CuCl}_{2} \cdot 2 \mathrm{H}_{2} \mathrm{O}, \mathrm{CuClOH} / \mathrm{CuCl}$, $\mathrm{Cu}_{2} \mathrm{Cl}(\mathrm{OH})_{3}, \mathrm{Cu}(\mathrm{OH})_{2} \mathrm{CuCO}_{3} / \mathrm{CuCO}_{3}, \mathrm{Cu}(\mathrm{OH})_{2}, \mathrm{CuSO}_{4} \cdot 5 \mathrm{H}_{2} \mathrm{O}, \mathrm{CuSiO}_{3} \cdot \mathrm{H}_{2} \mathrm{O}, \mathrm{CuBr}_{2}$ and $\mathrm{CuS}$. All standard compounds were analyzed with XRD and identified as pure, i.e. $<2 \%$ impurities, except the $\mathrm{CuClOH} / \mathrm{CuCl}$ and $\mathrm{Cu}(\mathrm{OH})_{2} \mathrm{CuCO}_{3} / \mathrm{CuCO}_{3}$. The $\mathrm{CuClOH} / \mathrm{CuCl}$ was identified as $\mathrm{CuClOH}$ with a small part $(\leq 7 \%) \mathrm{CuCl}$. The $\mathrm{Cu}(\mathrm{OH})_{2} \mathrm{CuCO}_{3} / \mathrm{CuCO}_{3}$ was identified by $\mathrm{XRD}$ and TGA as $\mathrm{Cu}(\mathrm{OH})_{2} \mathrm{CuCO}_{3}$ with a small part $(\sim 12 \%)$ of $\mathrm{CuCO}_{3}$. 
All XAS data were collected around the copper K-edge, which is the increase in absorption at energies equal to or higher than the binding energies of the innermost K (1s) electrons of copper. Copper K-edges spectrum were collected at room temperature and at ambient atmospheric pressure at beamline I811 using a $\mathrm{Si}(111)$ double crystal monochromator. The monochromator was detuned to $30 \%$ below maximum intensity to remove higher order harmonics. All spectra were calibrated by assigning the first inflection point of the $\mathrm{Cu}$ metal K-edge to $8.979 \mathrm{keV}$. The sample spectra were collected in fluorescence mode by either a Lytle detector or a solid state PIPS detector and the metal foil data for energy calibration were simultaneously collected in transmission mode by ionization chambers. The intensity of the primary beam, $\mathrm{I}_{0}$, was measured with an ionization chamber filled with $\mathrm{N}_{2}$ to 1.1 bar. The intensity of the beam after passing the sample $\left(\mathrm{I}_{1}\right)$ and after passing the $\mathrm{Cu}$ metal foil $\left(\mathrm{I}_{2}\right)$ were measured with ionization chambers filled with Ar to 0.1 bar and 2 bar respectively. Each XAS spectrum represents the average of two or more scans.

Data processing and evaluation was carried out using the EXAFSPAK software package ${ }^{26}$, as well as the Athena software ${ }^{27}$. The $a b$ initio modeling of the theoretical EXAFS features was done using the FEFF7 software ${ }^{28}$ and crystallographic data from the NIST/FIZ Inorganic Crystal Structure Database $^{29}$. This method indicates not only the distances to the neighbor (backscattering) atoms but also how many these atoms are and gives a measure of the disorder in the structure. Both the data region near the absorption edge (XANES) and the data in the extended region (EXAFS) were modeled using linear combination fitting (LCF) of data for standard compounds as well. The three methods of evaluation were then combined to conclusions about what copper species are present and their approximate relative concentrations in the samples. X-ray absorption spectroscopy is further described by e.g. Penner-Hahn ${ }^{30}$. 


\section{RESULTS}

The concentrations of major elements and copper in the ash samples are shown in Table 1 and the main crystalline compounds present are shown in Table 2.

Table 1. Chemical composition of ash samples from the waste fired combustor (main elements calculated as their most common oxides)

\begin{tabular}{|l|r|r|r|r|}
\hline $\begin{array}{l}\text { Element } \\
(\mathrm{mg} / \mathrm{kg} \text { dry ash) }\end{array}$ & \multicolumn{1}{l|}{ Bottom } & \multicolumn{1}{l|}{ Hopper } & \multicolumn{1}{l|}{ Cyclone } \\
\hline $\mathrm{Si}$ & 330000 & 300000 & 20000 & 30000 \\
\hline $\mathrm{Al}$ & 50000 & 70000 & 120000 & 20000 \\
\hline $\mathrm{Ca}$ & 40000 & 50000 & 120000 & 360000 \\
\hline $\mathrm{Fe}$ & 21000 & 34000 & 34000 & 6000 \\
\hline $\mathrm{K}$ & 25000 & 20000 & 17000 & 23000 \\
\hline $\mathrm{Mg}$ & 6000 & 8000 & 16000 & 10000 \\
\hline $\mathrm{Mn}$ & 500 & 1000 & 2200 & 600 \\
\hline $\mathrm{Na}$ & 2000 & 5000 & 7000 & 4000 \\
\hline $\mathrm{P}$ & 3000 & 6000 & 7000 & 2000 \\
\hline $\mathrm{Ti}$ & 300 & 1500 & 22000 & 190000 \\
\hline $\mathrm{Cl}$ & 700 & 2000 & 6000 & 17000 \\
\hline $\mathrm{S}$ & 400 & 3200 & 3200 & 5400 \\
\hline $\mathrm{Cu}$ & & 300 & 400 & 200 \\
\hline $\mathrm{Cr}$ & 1800 & & 30000 & 30000 \\
\hline
\end{tabular}


Table 2. Crystalline compounds identified by XRD

\begin{tabular}{|c|c|c|c|c|c|c|c|}
\hline Bottom & & Hopper & & Cyclone & & Filter & \\
\hline $\mathrm{SiO}_{2}$ & Major & $\mathrm{SiO}_{2}$ & Major & $\mathrm{SiO}_{2}$ & Major & $\mathrm{SiO}_{2}$ & Trace \\
\hline $\mathrm{KAlSi}_{3} \mathrm{O}_{8}$ & Major & $\mathrm{KAlSi}_{3} \mathrm{O}_{8}$ & Major & $\mathrm{KAlSi}_{3} \mathrm{O}_{8}$ & Major & & \\
\hline$(\mathrm{Ca}, \mathrm{Na}) \mathrm{AlSi}_{3} \mathrm{O}_{8}$ & Major & $(\mathrm{Ca}, \mathrm{Na}) \mathrm{AlSi}_{3} \mathrm{O}_{8}$ & Major & $(\mathrm{Ca}, \mathrm{Na}) \mathrm{AlSi}_{3} \mathrm{O}_{8}$ & Major & & \\
\hline & & & & $\mathrm{CaO}$ & Minor & $\mathrm{Ca}(\mathrm{OH})_{2}$ & Major \\
\hline $\mathrm{CaSiO}_{3}$ & Minor & $\mathrm{CaCO}_{3}$ & Minor & $\mathrm{CaCO}_{3}$ & Major & $\mathrm{CaCO}_{3}$ & Major \\
\hline & & & & $\mathrm{CaSO}_{4}$ & Minor & $\mathrm{CaSO}_{4}$ & Trace \\
\hline & & $\mathrm{Ca}_{3} \mathrm{Al}_{2} \mathrm{O}_{6}$ & Trace & $\mathrm{Ca}_{3} \mathrm{Al}_{2} \mathrm{O}_{6}$ & Trace & $\mathrm{Ca}_{3} \mathrm{Al}_{2} \mathrm{O}_{6}$ & Trace \\
\hline & & $\mathrm{Ca}_{2} \mathrm{Al}_{2} \mathrm{SiO}_{7}$ & Major & $\mathrm{Ca}_{2} \mathrm{Al}_{2} \mathrm{SiO}_{7}$ & Major & & \\
\hline & & Al metal & Trace & Al metal & Major & & \\
\hline & & & & & & $\mathrm{CaClOH}$ & Major \\
\hline & & & & & & $\mathrm{KCaCl}_{3}$ & Trace \\
\hline & & & & & & $\mathrm{NaCl}$ & Major \\
\hline & & & & & & $\mathrm{KCl}$ & Major \\
\hline $\mathrm{Fe}_{2} \mathrm{O}_{3}$ & Minor & $\mathrm{Fe}_{2} \mathrm{O}_{3}$ & Major & $\mathrm{Fe}_{2} \mathrm{O}_{3}$ & Minor & & \\
\hline $\mathrm{Fe}_{3} \mathrm{O}_{4}$ & Minor & $\mathrm{Fe}_{3} \mathrm{O}_{4}$ & Major & $\mathrm{Fe}_{3} \mathrm{O}_{4}$ & Minor & & \\
\hline
\end{tabular}

The results from the different types of evaluation of the XAS data for the four ash types (bottom ash, ash from the hopper which is the finer particle fraction of the bed ash, cyclone ash and filter ash) are presented below.

The linear combination fitting (LCF) along with the standards suggested in the LCF, are illustrated in Figure 1 for XANES and Figure 2 for $k^{3}$-weighted EXAFS. Results from the $a b$ initio FEFF modeling of the EXAFS spectra from the ashes are gathered in Table 3, along with crystallographic data of the reference compounds in Table 4. The distance between the central $\mathrm{Cu}$ atom and the backscattering atom is denoted as $R$. The coordination number, i.e. the number 
of backscattering atoms at a certain distance from the copper atom in the center, is denoted as $N$. Since the ash is a mixture containing several components, the coordination number will be an average of all copper atoms in the mix. The Debye-Waller parameter, $\sigma^{2}$, is a measure of the disorder in the structure. A low $\sigma^{2}$ value represents high certainty of $R$, while a higher $\sigma^{2}$ value represents more disorder. However, $\sigma^{2}$ and $N$ is closely linked to each other. A slight increase or decrease in both $N$ and $\sigma^{2}$ will give almost the same signal, which means that these numbers should be regarded more as an approximation than an exact measure.

Table 3. Inter-atomic distances obtained from the sample data

\begin{tabular}{|l|l|l|l|l|}
\hline Sample & Atoms & $R(\AA)$ & $N$ & $\sigma^{2}\left(\AA^{2}\right)$ \\
\hline Bottom ash & $\mathrm{Cu}-\mathrm{O}$ & 1.91 & 2.5 & 0.006 \\
\hline & $\mathrm{Cu}-\mathrm{Cu}$ & 2.56 & 1.3 & 0.005 \\
\hline Hopper ash & $\mathrm{Cu}-\mathrm{O}$ & 1.92 & 3.7 & 0.008 \\
\hline & $\mathrm{Cu}-\mathrm{Cu}$ & 2.52 & 0.7 & 0.005 \\
\hline & $\mathrm{Cu}-\mathrm{Cu}$ & 2.95 & 8.9 & 0.031 \\
\hline Cyclone ash & $\mathrm{Cu}-\mathrm{O}$ & 1.93 & 2.7 & 0.008 \\
\hline & $\mathrm{Cu}-\mathrm{Cu}$ & 2.55 & 1.7 & 0.008 \\
\hline & $\mathrm{Cu}-\mathrm{Cu}$ & 3.67 & 0.8 & 0.014 \\
\hline & $\mathrm{Cu}-\mathrm{Cu}$ & 4.47 & 3.3 & 0.014 \\
\hline Filter ash & $\mathrm{Cu}-\mathrm{Cu}$ & 4.97 & 1.7 & 0.007 \\
\hline & $\mathrm{Cu}-\mathrm{O}$ & 1.96 & 3.5 & 0.004 \\
\hline & $\mathrm{Cu}-\mathrm{Cl}$ & 2.76 & 1.8 & 0.017 \\
\hline & $\mathrm{Cu}-\mathrm{Cu}$ & 3.31 & 5.0 & 0.013 \\
\hline
\end{tabular}


Table 4. Inter-atomic distances and coordination numbers for pure compounds suggested in the modeling of EXAFS data

\begin{tabular}{|l|l|l|r|l|l|l|r|}
\hline Compound & Atoms & $R(\AA)$ & $N$ & Compound & Atoms & $R(\AA)$ & $N$ \\
\hline $\mathrm{Cu}$ metal & $\mathrm{Cu}-\mathrm{Cu}$ & 2.56 & 12 & $\mathrm{CuCl}$ & $\mathrm{Cu}-\mathrm{Cl}$ & 2.35 & 4 \\
\hline & $\mathrm{Cu}-\mathrm{Cu}$ & 3.61 & 6 & & $\mathrm{Cu}-\mathrm{Cu}$ & 3.83 & 12 \\
\hline & $\mathrm{Cu}-\mathrm{Cu}$ & 4.43 & 24 & $\mathrm{CuClOH}$ & $\mathrm{Cu}-\mathrm{O}$ & $1.98-2.02$ & 3 \\
\hline & $\mathrm{Cu}-\mathrm{Cu}$ & 5.11 & 12 & & $\mathrm{Cu}-\mathrm{Cl}$ & 2.29 & 1 \\
\hline $\mathrm{Cu}_{2} \mathrm{O}$ & $\mathrm{Cu}-\mathrm{O}$ & 1.84 & 2 & & $\mathrm{Cu}-\mathrm{Cl}$ & $2.70-2.72$ & 2 \\
\hline & $\mathrm{Cu}-\mathrm{Cu}$ & 3.01 & 12 & & $\mathrm{Cu}-\mathrm{Cu}$ & 3.04 & 1 \\
\hline $\mathrm{CuO}$ & $\mathrm{Cu}-\mathrm{O}$ & $1.95-1.96$ & 4 & & $\mathrm{Cu}-\mathrm{Cu}$ & $3.29-3.39$ & 5 \\
\hline & $\mathrm{Cu}-\mathrm{O}$ & 2.78 & 2 & $\mathrm{CuCr}_{2} \mathrm{O}_{4}$ & $\mathrm{Cu}-\mathrm{O}$ & 1.99 & 4 \\
\hline & $\mathrm{Cu}-\mathrm{Cu}$ & 2.90 & 4 & & $\mathrm{Cu}-\mathrm{O}$ & 3.50 & 12 \\
\hline & $\mathrm{Cu}-\mathrm{Cu}$ & 3.08 & 4 & & $\mathrm{Cu}-\mathrm{Cr}$ & 3.46 & 12 \\
\hline & $\mathrm{Cu}-\mathrm{Cu}$ & 3.17 & 2 & & $\mathrm{Cu}-\mathrm{Cu}$ & 3.62 & 4 \\
\hline & $\mathrm{Cu}-\mathrm{Cu}$ & 3.42 & 2 & $\mathrm{CuSO}_{4} \cdot 5 \mathrm{H}_{2} \mathrm{O}$ & $\mathrm{Cu}-\mathrm{O}$ & $1.93-1.97$ & 4 \\
\hline $\mathrm{Cu}(\mathrm{OH})_{2}$ & $\mathrm{Cu}-\mathrm{O}$ & $1.95-1.97$ & 4 & & $\mathrm{Cu}-\mathrm{O}$ & $2.38-2.43$ & 2 \\
\hline & $\mathrm{Cu}-\mathrm{O}$ & 2.36 & 1 & & $\mathrm{Cu}-\mathrm{S}$ & $3.55-3.68$ & 2 \\
\hline & $\mathrm{Cu}-\mathrm{O}$ & 2.92 & 1 & & & & \\
\hline & $\mathrm{Cu}-\mathrm{Cu}$ & 2.95 & 2 & & & & \\
\hline & $\mathrm{Cu}-\mathrm{Cu}$ & 3.34 & 4 & & & & \\
\hline
\end{tabular}




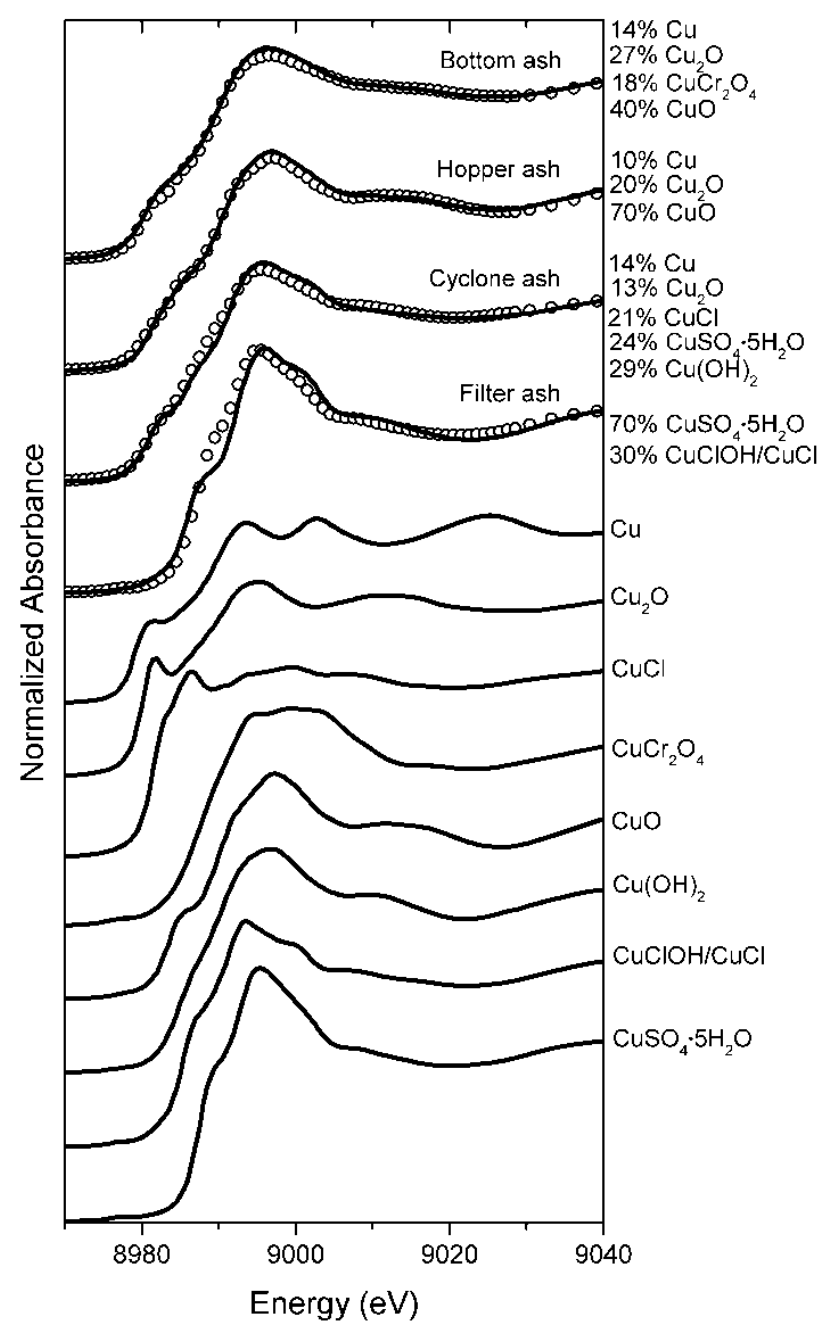

Figure 1. Cu K-edge XANES data for ash samples, standard compounds and linear combination fit models. Solid lines represent measured data and dotted lines the model results. 


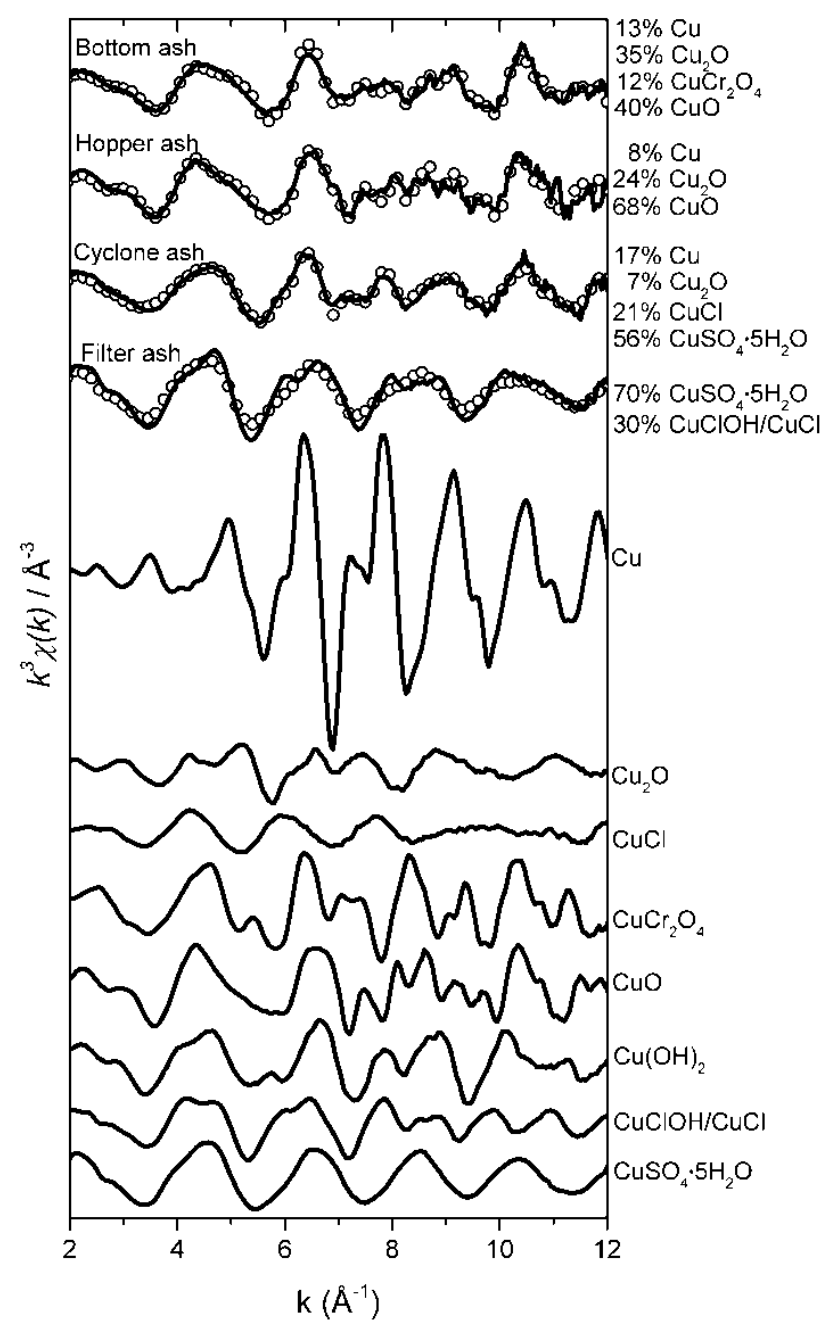

Figure 2. Cu K-edge $\mathrm{k}^{3}$-amplified EXAFS data for ash samples, standard compounds and linear combination fit models. Solid lines represent measured data and dotted lines the model results.

Bottom ash. The Cu K-edge for the bottom ash starts at lower energy than the edges for the $\mathrm{Cu}(\mathrm{II})$ compounds used as standards and K-edges for other $\mathrm{Cu}(\mathrm{II})$ compounds found in literature. This shows that the copper speciation in the bottom ash comprises some $\mathrm{Cu}(0), \mathrm{Cu}(\mathrm{I})$ or a combination of these. It is however impossible to model the entire XANES region for the bottom ash without the addition of some $\mathrm{Cu}(\mathrm{II})$ as well. Thus, the results show that copper occurs in several oxidation states in this ash. Previous results of this ash ${ }^{31}$ accidentally gave a total of 
$103 \%$ which has been corrected for here using the same fractional amounts but summing up to $100 \%$. The corrected results show that a combination of $17 \% \mathrm{Cu}, 26 \% \mathrm{Cu}_{2} \mathrm{O}$ and $56 \% \mathrm{CuO}$ gave a rather good fit. With an addition of $\mathrm{CuCr}_{2} \mathrm{O}_{4}$, which was not available as reference compound in the evaluation discussed in the previous publication, the fit becomes even better. The best fit was obtained with the combination $14 \% \mathrm{Cu}, 27 \% \mathrm{Cu}_{2} \mathrm{O}, 18 \% \mathrm{CuCr}_{2} \mathrm{O}_{4}$ and $40 \%$ $\mathrm{CuO}$, which is illustrated in Figure 1. A closer look at this XANES fit shows that it is not perfect, which is for example seen at the plateau around $8984 \mathrm{eV}$. This indicates that, even though a large number of copper compounds were included in the library of standards in this investigation, some compounds may be missing. It is however clear that this bottom ash contains $10-20 \%$ $\mathrm{Cu}(0), 25-35 \% \mathrm{Cu}(\mathrm{I})$ and the rest is $\mathrm{Cu}(\mathrm{II})$.

The linear combination fitting of the EXAFS region (Figure 2) of the bottom ash XAS data also showed that the best model for the speciation included $\mathrm{CuO}$ and $\mathrm{Cu}$ metal. Other reference compounds that could be included in models along with $\mathrm{CuO}$ and $\mathrm{Cu}$ were $\mathrm{CuCr}_{2} \mathrm{O}_{4}$, $\mathrm{CuSiO}_{3} \cdot \mathrm{H}_{2} \mathrm{O}, \mathrm{Cu}_{2} \mathrm{O}$ and brass. One typical combination that fits quite well is $13 \% \mathrm{Cu}, 35 \%$ $\mathrm{Cu}_{2} \mathrm{O}, 12 \% \mathrm{CuCr}_{2} \mathrm{O}_{4}$ and $40 \% \mathrm{CuO}$, i.e. a similar combination as was indicated by modeling of the XANES region of the data.

The $a b$ initio modeling of the EXAFS region (Table 3) suggested a Cu-O distance (1.91 $\AA$ ) which is too short to be referred to as a typical $\mathrm{Cu}-\mathrm{O}$ distance in $\mathrm{Cu}(\mathrm{II})$ compounds and longer than the $\mathrm{Cu}-\mathrm{O}$ distance for $\mathrm{Cu}(\mathrm{I})$ compounds (cf. Table 4). This shows that both types are present. The data also showed a short $\mathrm{Cu}-\mathrm{Cu}$ distance $(2.56 \AA)$ that fits well with the distances present in copper metal. Thus, the distances and coordination numbers $(\mathrm{N})$ obtained fit well with the approximate concentrations given by the linear combination fits presented above. 
Filter ash. The XAS spectrum obtained for the filter ash looks completely different from the spectrum for the bottom ash. The Cu K-edge of the fly ash spectrum starts at an energy similar to those of the $\mathrm{Cu}(\mathrm{II})$ compounds studied. This shows that copper species with low oxidation numbers can only be present in small amounts in this sample.

From linear combination fitting of the EXAFS region, with two and more compounds, it was concluded that the best fits contain $\mathrm{CuSO}_{4} \cdot 5 \mathrm{H}_{2} \mathrm{O}$ in combination with hydroxides and/or chlorides. The combination of $70 \% \mathrm{CuSO}_{4} \cdot 5 \mathrm{H}_{2} \mathrm{O}$ and $30 \% \mathrm{CuClOH} / \mathrm{CuCl}$ gave a rather good fit in the EXAFS region as well as for the XANES region (Figures 1 and 2). However, it is not perfect which is for example seen at the plateau around $8989 \mathrm{eV}$. This indicates the presence of a hitherto unknown compound in the mix.

The $a b$ initio modeling of the EXAFS region (Table 3) indicated a dominating $\mathrm{Cu}-\mathrm{O}$ distance of $1.96 \AA$, which fits quite well with the crystallographic data for $\mathrm{CuSO}_{4} \cdot 5 \mathrm{H}_{2} \mathrm{O}$ (cf. Table 4). The model also gave a Cu-Cu distance of $3.31 \AA$, which along with the $\mathrm{Cu}-\mathrm{O}$ at $1.96 \AA$ fits well with copper hydroxides. There is also a small signal connected to a $\mathrm{Cu}-\mathrm{Cl}$ distance at $2.76 \AA$, which fits with several chlorides. Since there is also a lack of strong signals from heavy backscattering atoms, other than $\mathrm{Cu}$ atoms at $3.31 \AA$ from the central $\mathrm{Cu}$ atom, it was possible to exclude quite a lot of compounds. The distances and coordination numbers $(\mathrm{N})$ given by the models fit well with a mix of sulfates, hydroxides and chlorides. In Figure 1 and 2, this is represented by a mix consisting of $70 \% \mathrm{CuSO}_{4} \cdot 5 \mathrm{H}_{2} \mathrm{O}$ and $30 \% \mathrm{CuClOH} / \mathrm{CuCl}$.

Hopper ash. The hopper ash XAS spectrum looks quite similar to that of the bottom ash which is logical since the ash collected in this hopper consists of the finer particle fractions of the bed ash. The Cu K-edge for the hopper ash starts at a slightly higher energy than observed for the bottom ash, but still at lower energy than for the $\mathrm{Cu}(\mathrm{II})$ compounds used as references. This 
shows that part of the copper content has an oxidation state of zero and/or one but the mayor part is $\mathrm{Cu}(\mathrm{II})$. Linear combination fitting of the XANES part of the data showed that a combination of $10 \% \mathrm{Cu}, 20 \% \mathrm{Cu}_{2} \mathrm{O}$ and $70 \% \mathrm{CuO}$ described the XANES spectrum of the hopper ash sample quite well (Figure 1). The models do not give a perfect fit, but a good estimation of the concentrations of copper in different oxidation states in the sample is $5-10 \% \mathrm{Cu}(0), 15-25 \%$ $\mathrm{Cu}(\mathrm{I})$ and $65-75 \% \mathrm{Cu}(\mathrm{II})$. Using the bottom ash as one of the reference compounds makes a better fit when it is combined with a decrease in $\mathrm{Cu}$ metal and increase in $\mathrm{CuO}$. This indicates that there might be some hitherto unknown copper compound in the hopper ash as well as in the bottom ash, but it is also quite clear how the copper species changes between the two ashes.

A comparison of the EXAFS spectrum (Figure 2) obtained for the hopper ash sample with EXAFS data for standard compounds shows a great resemblance between the spectra for hopper ash and $\mathrm{CuO}$, for example the peaks looking like five "fingers" located at $\mathrm{k}=7-10 \AA^{-1}$. From linear combination fitting of the EXAFS region, using two and more compounds in the model, it was concluded that the best fits contain $\mathrm{CuO}$ in combination with a small amount ( $10 \%)$ of $\mathrm{Cu}$ or a larger amount ( $60 \%$ ) of bottom ash. One example of a good fit is the combination of $8 \%$ $\mathrm{Cu}, 24 \% \mathrm{Cu}_{2} \mathrm{O}$ and $68 \% \mathrm{CuO}$.

The $a b$ initio modeling of the EXAFS region (Table 3) gave a Cu-O distance of $1.92 \AA$ which is shorter than typical $\mathrm{Cu}(\mathrm{II})-\mathrm{O}$ distances and longer than $\mathrm{Cu}(\mathrm{I})-\mathrm{O}$ distances (cf. Table 4). It is most likely that this, the most prominent, signal is caused by a mixture of these two $\mathrm{Cu}-\mathrm{O}$ distances. The model also showed a long $\mathrm{Cu}-\mathrm{Cu}$ distance $(2.95 \AA)$ which fits well with both $\mathrm{CuO}$ (four copper atoms at $2.90 \AA$ from the central $\mathrm{Cu}$ atom, four at $3.08 \AA$ and two at $3.17 \AA$ ) and $\mathrm{Cu}_{2} \mathrm{O}$ (twelve copper atoms at $3.01 \AA$ ). The long $\mathrm{Cu}-\mathrm{Cu}$ distance returned a high $\sigma^{2}$ value (i.e. high disorder), which in turn is expected if there is such a variation in distance mixed in the same 
signal. In between the two mentioned signals there was a third weaker signal which was modeled as a $\mathrm{Cu}-\mathrm{Cu}$ at $2.52 \AA$ which is much too short to be caused by anything but metallic copper. The distances and coordination numbers $(N)$ given by the models fit well with a mix of approximately $5 \% \mathrm{Cu}, 15 \% \mathrm{Cu}_{2} \mathrm{O}$ and $80 \% \mathrm{CuO}$ which is similar to the results shown by the linear combination fitting.

Cyclone ash. The XAS spectrum of cyclone ash shares some similarities with both the filter ash spectra and the hopper ash spectra. The Cu K-edge starts at a lower energy for the cyclone ash than for the filter ash, indicating more $\mathrm{Cu}(0)$ and $\mathrm{Cu}(\mathrm{I})$ in the cyclone ash. The rest of the XANES region indicates that $\mathrm{Cu}(\mathrm{II})$ is the dominating oxidation state. A good estimation of the concentrations of copper in different oxidation states in the sample is $10-20 \% \mathrm{Cu}(0), 25-35 \%$ $\mathrm{Cu}(\mathrm{I})$ and $50-60 \% \mathrm{Cu}(\mathrm{II})$. Linear combination fitting of the XANES part of the data showed that a combination of $14 \% \mathrm{Cu}, 21 \% \mathrm{CuCl}, 13 \% \mathrm{Cu}_{2} \mathrm{O}, 24 \% \mathrm{CuSO}_{4} \cdot 5 \mathrm{H}_{2} \mathrm{O}$ and $29 \% \mathrm{Cu}(\mathrm{OH})_{2}$ described the XANES spectrum of the cyclone ash sample quite well, which is illustrated in Figure 1. The linear combination modeling did also show that the data are best described by combinations including either the hopper ash or the filter ash as one component. One example of a good combination is filter ash, with an addition of $\mathrm{Cu}$ metal, $\mathrm{CuCl}, \mathrm{Cu}_{2} \mathrm{O}$ and $\mathrm{CuO}$. Another example of a good combination is hopper ash, with a decrease in $\mathrm{CuO}$ and increase in $\mathrm{CuSO}_{4} \cdot 5 \mathrm{H}_{2} \mathrm{O}$. This indicates that there might be a hitherto unknown compound in all of the ashes, but it is also a good indication of how the copper compounds change between the different ash flows. The copper speciation in the cyclone ash is basically that of a mix of hopper ash and filter ash with some extra copper metal and $\mathrm{Cu}(\mathrm{I})$ compounds.

The linear combination fitting that best described the EXAFS region (Figure 2) of the data included the filter ash or $\mathrm{CuSO}_{4} \cdot 5 \mathrm{H}_{2} \mathrm{O}$ as one component and pure copper metal as another. It is 
probable that the cyclone ash contains copper in another compound as well, but it is not evident from the EXAFS data which one. Judging by the results from the XANES region, the third component need to be some form of $\mathrm{Cu}(\mathrm{I})$ compound. One LCF result that fits quite well is a combination of $17 \% \mathrm{Cu}, 7 \% \mathrm{Cu}_{2} \mathrm{O}, 21 \% \mathrm{CuCl}$ and $56 \% \mathrm{CuSO}_{4} \cdot 5 \mathrm{H}_{2} \mathrm{O}$.

The $a b$ initio modeling of the EXAFS region (Table 3) showed a prominent signal from a Cu-O distance of $1.93 \AA$ which is a little too short to be involving just $\mathrm{Cu}(\mathrm{II})$ and much too long to indicate only $\mathrm{Cu}(\mathrm{I})$ (cf. Table 4). It is most likely a mix of these, with a majority of $\mathrm{Cu}(\mathrm{II})$. The model also gave four different $\mathrm{Cu}-\mathrm{Cu}$ distances (2.55, 3.67, 4.47 and $4.97 \AA$ ) which all fit well with pure copper metal. The distances and coordination numbers $(N)$ given by the models fit well with a mix of a small amount ( $15 \%$ ) of metallic copper and a larger amount of $\mathrm{CuSO}_{4} \cdot 5 \mathrm{H}_{2} \mathrm{O}$, or some other compound with a similar structure, combined with a small amount of $\mathrm{Cu}(\mathrm{I})$ with oxygen as a nearest neighboring atom, such as $\mathrm{Cu}_{2} \mathrm{O}$.

\section{DISCUSSION}

Sometimes it was difficult to arrive at a truly certain speciation, which could indicate that the selection of standard compounds still does not cover all possibilities. It could also indicate that the compounds present in the ashes are not well crystallized or present in small units (crystallites) which would be the case for rapidly formed compounds. Since copper can be involved in many transformation reactions in both combustion chamber and flue gas channel it is probable that the ashes contains rapidly formed copper compounds.

As shown in the results the average oxidation state of copper is quite low in the combustion bed and increases as the copper species are transported through the flue gas channel and the flue gas treatment system. The copper with lower oxidation numbers in the bottom ash could be an effect of reducing conditions in the burning waste particles in the bed. The fluidizing air, running 
through the bed, is only a part of the total combustion air. The remaining air is introduced above the bed, in the freeboard, through the secondary air nozzles. It is also possible that larger pieces of metal react slowly and do not have the time to reach equilibrium. The hopper ash, on the other hand, contains smaller pieces, with a larger surface-to-mass ratio. It has also been in contact with the secondary air, which all leads to higher concentrations of $\mathrm{Cu}(\mathrm{II})$, i.e. $\mathrm{CuO}$. The volatile copper chlorides are still in a gas phase and the copper sulfate is not stable at the high temperatures prevailing in the combustion bed and the hopper ${ }^{32}$.

The mixed copper-chromium oxide, $\mathrm{CuCr}_{2} \mathrm{O}_{4}$, suggested as a part of the bottom ash could be formed through a solid state reaction between copper oxide and chromium oxide. The standard compound used in these tests was prepared in a simple experiment where $\mathrm{Cu}_{2} \mathrm{O}$ and $\mathrm{Cr}_{2} \mathrm{O}_{3}$ were mixed together at a stoichiometric ratio, heated to $700^{\circ} \mathrm{C}$ for $24 \mathrm{~h}$ in air and later identified as pure $\mathrm{CuCr}_{2} \mathrm{O}_{4}$ using XRD (unpublished results). It has also been identified as an ash product in other combustion experiments and suggested as the dominant chromium species under certain thermodynamic conditions ${ }^{33-34}$. It will however not be present in higher concentrations than $8 \%$ of the total copper in the bottom ash, considering the chemical composition given in Table 1.

It is obvious that the copper metal that was found in the cyclone ash is not present there due to a low air to fuel ratio, since it has been exposed to the secondary air before it reaches the cyclone. It is possible that small pieces of copper metal, e.g. originating from electronic waste ${ }^{1-5}$, have traveled all the way to the cyclone before getting separated. The $\mathrm{Cu}(\mathrm{I})$ that was found in the cyclone could very well be due to surface reactions on those metal pieces, either with oxygen or $\mathrm{HCl}$ in the flue gases. The cyclone ash shows similarities with both the hopper ash and the filter ash, which is understandable since the cyclone ash has traveled through the hopper and part of the filter ash has travelled through the cyclone. 
The filter ash XAS spectra were the most difficult to evaluate and to explain by probable copper compounds, but the best estimate is a $\mathrm{Cu}(\mathrm{II}) \mathrm{mix}$ of sulfates, hydroxides and chlorides. The chlorides could very well have travelled all the way from the furnace to the filter before they condensed, or reactions between other copper compounds and $\mathrm{HCl}$ may have occurred along the way $^{32,35}$. The presence of hydroxides could be caused by reaction with water vapor, either in the flue gas or after the ash was collected. The ashes have been stored in air tight containers but during handling they have been in contact with the air. The sulfates could have been formed through a reaction with $\mathrm{SO}_{\mathrm{X}}$ in the flue gas.

Copper speciation results such as those presented here can, if collected for a large enough number of combustion cases, give indications of the chemistry of copper in ashes from waste combustion. In addition, such results have given plausible explanations for differences in copper leaching yields obtained in experiments aiming at developing a method to recover metals from MSWI ash. Methods based on acid leaching as well as on leaching with ammonium based leachates have been shown to give poor results for ashes containing copper silicate and other compounds with low solubility ${ }^{36}$.

\section{CONCLUSIONS}

The bottom ash contains a mixture of copper(0), copper(I) and copper(II) in the relative concentrations $10-20 \% \mathrm{Cu}(0), 25-35 \% \mathrm{Cu}(\mathrm{I})$ and $55-65 \% \mathrm{Cu}(\mathrm{II})$. The major part of the $\mathrm{Cu}(0)$ is most likely pure copper. The major parts of $\mathrm{Cu}(\mathrm{I})$ and $\mathrm{Cu}(\mathrm{II})$ are most likely oxides (e.g. $\mathrm{Cu}_{2} \mathrm{O}$ and $\mathrm{CuO}$ ) and mixed oxides, such as the copper-chromium-oxide $\mathrm{CuCr}_{2} \mathrm{O}_{4}$ which might occur in concentrations up to $8 \%$.

The hopper ash seems to contain more of $\mathrm{CuO}$ and less of $\mathrm{Cu}$ metal than the bottom ash does, but otherwise these two ashes are quite similar in their copper composition. The best 
approximation of the mix of oxidation states in the hopper ash is 5-10\% $\mathrm{Cu}(0), 15-25 \% \mathrm{Cu}(\mathrm{I})$ and $65-75 \% \mathrm{Cu}(\mathrm{II})$. The major part of the $\mathrm{Cu}(\mathrm{II})$, and thereby also the major part of the copper in the ash, is most likely $\mathrm{CuO}$. The $\mathrm{Cu}(\mathrm{I})$ and the $\mathrm{Cu}(0)$ is most likely $\mathrm{Cu}_{2} \mathrm{O}$ and pure copper metal.

The cyclone ash contains less of $\mathrm{CuO}$ than the hopper ash does. The results also showed that the cyclone ash contains more $\mathrm{Cu}(0)$ and $\mathrm{Cu}(\mathrm{I})$ than the filter ash does. A good estimation of the concentrations of copper in different oxidation states is $10-20 \% \mathrm{Cu}(0), 25-35 \% \mathrm{Cu}(\mathrm{I})$ and 50-60 \% Cu(II). The $\mathrm{Cu}(0)$ is most likely pure copper metal. The most common chemical surrounding of copper(I) is less certain, but some portion of it does most likely have oxygen as a nearest neighboring atom. The best estimate of $\mathrm{Cu}(\mathrm{II})$ is a mix of $\mathrm{Cu}(\mathrm{OH})_{2}$ and $\mathrm{CuSO}_{4} \cdot 5 \mathrm{H}_{2} \mathrm{O}$, possibly also $\mathrm{CuO}$.

The filter ash contains mainly copper in oxidation state II, most likely in a mixture of several compounds. One major part of this mix is $\mathrm{CuSO}_{4} \cdot 5 \mathrm{H}_{2} \mathrm{O}$, or some other compound with a similar structure. Other parts of the mix could be different hydroxides and chlorides.

AUTHOR INFORMATION

Corresponding Author

*Henric Lassesson, MSc

Department of Chemical and Biological Engineering

Industrial Materials Recycling

Chalmers University of Technology

SE-412 96 Göteborg, Sweden

Phone: +46 317722945

Email: henric.lassesson@chalmers.se 


\section{Author Contributions}

The manuscript was written through contributions of all authors. All authors have given approval to the final version of the manuscript.

\section{Funding Sources}

Swedish Energy Agency

Chalmers Area of Advance Energy

\section{ACKNOWLEDGEMENT}

The authors want to thank Dr. Stefan Carlson at beamline I811 and the Maxlab staff for making the XAS measurements possible. Dr Katarina Norén at MaxIV Laboratory, Lund and Professor Ingmar Persson, Swedish Agricultural University, Uppsala are also thanked for helpful discussions. The work was funded by the Swedish Energy Agency and Chalmers Area of Advance Energy which is gratefully acknowledged. The work has been carried out within the Graduate School Polytechnic Waste Research in Sweden - POWRES funded by FORMAS, Sweden.

\section{REFERENCES}

(1) Mattsson Petersen, C.; Berg, P. E.O.; Lars Rönnegård, L. Quality control of waste to incineration - waste composition analysis in Lidköping, Sweden. Waste Management \& Research 2005, 23, 527-533

(2) Bernstad, A.; la Cour Jansen, J.; Aspegren, H. Property-close source separation of hazardous waste and waste electrical and electronic equipment - A Swedish case study. Waste Management, 2011, 31 (3), 536-543 
(3) Leander, J.; Sernland, M. Report U2011:04, Avfall Sverige - Swedish Waste Management, 2011

(4) Riber, C. Evaluation of Waste Specific Environmental Impacts from Incineration. Ph.D. Thesis, Institute of Environment \& Resources, Technical University of Denmark, October 2007, ISBN 978-87-91855-46-7

(5) Riber, C.; Petersen, C.; Christensen, T.H. Chemical composition of material fractions in Danish household waste, Waste Management, 2009, 29 (4), 1251-1257

(6) Stanmore, B.R. The formation of dioxins in combustion systems, Combustion and Flame, 2004, 136 (3), 398-427

(7) Karlsson, S.; Carlsson, P.; Åberg, D.; Karlfeldt Fedje, K.; Krook, J.; Steenari, B-M. What is required for the viability of metal recovery from municipal solid-waste incineration fly ash? - Design and assessment of a process plant for copper extraction, Linnaeus ECO-TECH '10, Kalmar, Sweden, 2010, November 22-24

(8) Karlfeldt Fedje, K.; Ekberg, C.; Skarnemark, G.; Pires, E.; Steenari, B-M. Initial studies of the recovery of $\mathrm{Cu}$ from MSWI fly ash leachates using solvent extraction, Waste Management \& Research 2012, 30(10) 1072-1080

(9) Tessier, A.; Campbell, P.G.C.; Bisson, M. ANALYTICAL CHEMISTRY, 1979, 51, 844851

(10) Van Herck, P.; Vandecasteele, C. Waste Management, 2001, 21, 685-694

(11) Fernández Alborés, A.; Pérez Cid, B.; Fernández Gómez, E.; Falqué López, E. Comparison between sequential extraction procedures and single extractions for metal partitioning in sewage sludge samples Analyst, 2000,125, 1353-1357

(12) Funatsuki, A.; Takaoka, M.; Oshita, K.; Takeda, N., Methods of Determining Lead Speciation in Fly Ash by X-ray Absorption Fine-Structure Spectroscopy and a Sequential Extraction Procedure, Analytical Sciences, 2012, 28 (5), 481-490

(13) Hsiao, M. C.; Wang, H. P.; Huang, Y.-J.; Yang, Y. W. J. Synchrotron Rad. 2001 8, 931933

(14) Hsiao, M. C.; Wang, H.P.; Yang, Y. W. EXAFS and XANES Studies of Copper in a Solidified Fly Ash, Environmental Science \& Technology 200135 (12), 2532-2535

(15) Hsiao, M. C.; Wang, H.P.; Wei, Y.L.; Chang, J.-E.; Jou, C.J. Speciation of copper in the incineration fly ash of a municipal solid waste, Journal of Hazardous Materials, 2002, 91 (1-3), 301-307 
(16) Hsiao, M. C.; Wang, H.P.; Chang, J.-E.; Peng, C.Y. Tracking of copper species in incineration fly ashes, Journal of Hazardous Materials, 2006, 138 (3), 539-542

(17) Hsiao, M. C.; Wang, H.P.; Peng, C.Y.; Huang, C. H.; Wei, Y-L., Chemical Structure of Copper in Incineration Dry Scrubber and Bag Filter Ashes. AIP Conf. Proc. 2007, 882, 286, DOI:10.1063/1.2644503

(18) Huang, Y-C.; H. Wang, P.; Huang, H-L.; Huang, Y-J.; Chang, J-E.; Wei, Y-L. Speciation of copper in plasma-melted slag, Journal of Electron Spectroscopy and Related Phenomena, 2007, 156-158, 214-216,

(19) Tuan, Y.-J.; Wang, H. P.; Chang, J.-E.; Chao, C.-C.; Tsai, C.-K. Speciation of copper in the thermally stabilized slag, Nuclear Instruments and Methods in Physics Research Section A: Accelerators, Spectrometers, Detectors and Associated Equipment, 2010, 619 (1-3), 316-318

(20) Takaoka, M.; Shiono, A.; Yamamoto, T.; Uruga, T.; Takeda, N.; Tanaka, T.; Oshita, K.; Matsumoto, T.; Harada, H. Relationship between dynamic change of copper and dioxin generation in various fly ash, Chemosphere, 2008, 73 (1), Supplement, August, Pages S78-S83

(21) Takaoka, M.; Shiono, A.; Nishimura, K.; Yamamoto, T.; Uruga, T.; Takeda, N.; Tanaka, T; Oshita, K.; Matsumoto, T.; Harada, H. Dynamic Change of Copper in Fly Ash during de Novo Synthesis of Dioxins. Environmental Science \& Technology 2005, 39 (15), 5878-5884

(22) Takaoka, M.; Yamamoto, T.; Shiono, A.; Takeda, N.; Oshita, K.; Matsumoto, T.; Tanaka, T. The effect of copper speciation on the formation of chlorinated aromatics on real municipal solid waste incinerator fly ash, Chemosphere, 2005, 59 (10), 1497-1505

(23) Tian, S.; Yu, M.; Wang, W.; Wang, Q.; Wu. Z. Investigating the Speciation of Copper in Secondary Fly Ash by X-ray Absorption Spectroscopy. Environmental Science \& Technology 2009, 43 (24), 9084-9088

(24) Abbas, Z.; Steenari, B-M.; Lindqvist, O. A study of Cr(VI) in ashes from fluidized bed combustion of municipal solid waste: leaching, secondary reactions and the applicability of some speciation methods, Waste Management, 2001, 21 (8) 725-739

(25) Abbas, Z.; Partovi Moghaddam, A.; Steenari, B-M. Release of salts from municipal solid waste combustion residues, Waste Management, 2003, 23 (4) 291-305 
(26) George, G. N.; Pickering, I. J. EXAFSPAK - A Suite of Computer Programs for Analysis of X-ray Absorption Spectra. SSRL, Stanford, CA, 2000

(27) Ravel, B.; Newville, M. ATHENA, ARTEMIS, HEPHAESTUS: data analysis for X-ray absorption spectroscopy using IFEFFIT. Journal of Synchrotron Radiation, 2005, 12, 537-541

(28) Zabinsky, S.; Rehr, J.; Ankudnov, A.; Albers, R.; Eller, M. Multiple-scattering calculations of x-ray-absorption spectra. Physical Review B, 1995, 52, 2995-3008

(29) Inorganic Crystal Structure Database 1.9.1 (release 2012-2). FIZ/NIST: Gaitensburg, MD

(30) Penner-Hahn, J. E. X-ray absorption spectroscopy in coordination chemistry, Coordination Chemistry Reviews, 1999, 190-192, 1101-1123

(31) Lassesson, H.; Steenari, B-M. Possibilities of ash speciation with synchrotron based Xray absorption spectroscopy (XAS), Proceedings for the $21^{\text {st }}$ International Conference on Fluidized Bed Combustion, Naples (Italy) June 3-6, 2012, ID99

(32) Weast, R. C. ed, Handbook of Chemistry and Physics, $56^{\text {th }}$ edition, 1975, CRC Press Inc, ISBN 0-87819-455-X

(33) Lundholm, K.; Boström, D.; Nordin,A.; Schukarev. A. Fate of Cu, Cr, and As During Combustion of Impregnated Wood with and without Peat Additive. Environmental Science \& Technology, 2007, 41 (18), 6534-6540

(34) Lundholm, K.; Rogers, J. M.; Haynes, B. S.; Boström, D.; Nordin, A. Fate of Cu, Cr, and As during the Combustion Stages of CCA-Treated Wood Fuel Particles. Energy \& Fuels 2008, 22 (3), 1589-1597

(35) Verhults, D.; Buekens, A.; Spencer, P. J.; Eriksson, G. Environ. Sci. Technol. 1996, 30, 50

(36) Karlfeldt Fedje, K. Metals in MSWI fly ash - problems or opportunities? PhD thesis Department of Chemical and Biological Engineering, Chalmers University of Technology, Gothenburg, Sweden, 2010, ISBN 978-91-7385-386-6 